\title{
Cavitation in the mixing zone of a submerged jet
}

\section{Cavitation dans la zone de mélange d'un jet noyé}

\author{
PAR Hunter ROUSE
}

HOWA INSTHETE OF IIMUATILE MESEARCH *

\begin{abstract}
Whereas incipient cavitation at "streamlined boundary can be predicted bij potential theory, that occurring at a surface of discontinuty depends upon correlation of the turbulent velocily and pressure flactuations. Measure. ments of such fluctuations in a submerged je: are presented. loqether with dired obsermations of the cravitution phenomenon.
\end{abstract}

\begin{abstract}
La thérie polentielle permel de préboir l'apparilion de la cavitation sur un profil aérodynamique; son apparition sur une surface de discontinaté est fonction de la corrélation des fluctuations turbulentes de vitesse of de pression. Mesure de ces fluctuations dans un jel noye; observation globale du phénomène de cavitation.
\end{abstract}

\section{INTRODUCTION}

Whenever the pressure intensity within a llowing licpuid is reduced locally to the point of vaporization, vapor cavities form, persist momentarily, and then collapse as the pressure intensity in their vicinity increases. This flow phenomenon, known as caritation, is generally to be avoided, because of the energy loss, boundary damage, and noise which it entails. Means are hence required of predicting its occurrenec in terms of known flow characteristies.

There are two inherently different conditions ${ }^{\prime}$ flow which can produce the local pressure drop upon which cavitation depends. The first of these is the acceleration of a liquid as it passes along a curved boundary, the point of minimum intensity then lying at the boundary itself. The second is the generation of vortices within a liquid as it enters a zone of velocity discontinuity, the points of minimum intensity then being more or less remote from the boundary. In the former case the pressure change depends upon the characteristics of the mean motion,

\footnotetext{
* State Eniversity of Iowa, Iowa City (U.S.A.)
}

Toutes les fois que, à l'intéricur d'un liquide en mouvement, la valeur de la pression s'abaisse localement jusqu'à celle de la tension de vapeur, il apparait des bulles de vapeur qui se maintiennent un moment puis qui disparaissent lorsque la pression dans leur voisinage s'accroît : ce phénomène, connu sous le nom de cavitation, est en général à éviter, car il s'accompagne d'une perte d'énergie, d'une détérioration des parois et de bruit. On a donc cherché le moyen de prévoir son apparition en fonction des caractéristiques connues de l'écoulement.

Il existe deux cas d'écoulement tout à fait différents susceptibles de produire l'abaissement local de pression qui est à l'origine de la cavitation. Le premier cas correspond à l'accélération que subit un liquide lorsqu'il s'écoule le long d'une paroi courbe : le point de pression minimum se trouve alors sur la paroi même. Le second cas correspond aux tourbillons prenant naissance à l'intérieur d'un liquide lorsqu'il pénètre dans une zone de disćontinuité de vitesse: les points de pression minimum s'écartent alors plus ou moins de la paroi. Dans le premier cas, la variation de pression dépend des caractéristi- 
whereas in the latter it is the secondary motion which is directly involved.

For patterns of steady flow which are governed in form by the houndary geonetry, use of the potential theory has been found to permit rather accurate prediction of the flow conditions at which the vapor pressure of the licquid will be attained at any bonndary point. It is possible, in other words, to determine by analytical means the magnitude of a general cavitation index at which the vaporization process can be expeeted to begin. This index is of the form

$$
=\frac{p_{0}-\frac{p}{p}}{\left.\rho u_{0}\right)^{2} / 2}
$$

in which $p_{11}$ and $u_{0}$ are the ambient values of the pressure intensity and the relocity, and $p_{n}$ and $p$ are the rapor pressure and the density of the liquid. Experiments by many investigators have shown that a close agreement exists between analysis and measurement for flow without separation. Once separation occurs, however, cavitation is found to commence at magnitudes of $\sigma$ which are considerably greater than those indicated by the pressure distribution along the boundary itself $[1]^{*}$, because far lower intensities of pressure then ocen within the eddies gencrated in the zone of velocity discontinuity. As yet no analytical means of evaluating these pressure intensities is at hand.

Efflux from a submerged orifice or nozzle represents an extreme case of separation, for the resulting processes of eddy generation and diffusion control not only the secondary motion but the mean motion as well. In other words, the boundary form has essentially no effect upon the pressure distribution, and the ambient pressure intensity $p_{0}$ also represents with very elose approximation the mean intensity at ail points. In order to predict the conditions under which a submerged jet will begin to cavilate, it is essential that the pressure characteristies of the secondary motion be relaled in some manner to the mean relocity of the jet itself. Both the gross and the detailed aspeets of this problem have been under inrestigation at the Iowa Inslitule of Hydraulic Research since 1949, and the present paper is a revier of progress that has been made to date.

\footnotetext{
"Numbers belanen bracliels rojes lo the list ol relerences at the end.

- Les chiffres entre cocheds renvoient a la Bibliographie à la fin de lanticle.
}

ques du mouvement moyen; dans le second eas, au contraire, les fluctuations turbulentes sont directement en cause.

Pour les réseaux d'écoulement permanent, dont le dessin est guidé par la disposition géométrique des parois, on a pu, en se servant de la théorie potentielle, prévoir de faccon assez précise les conditions d'écoulenenl pour lesquelles la tension de vapeur du liquide se trouve atteinte en un point quelconque de la paroi. Il est, en d'autres termes, possible de déterminer analytiquement la valeur d'un coefficient général de cavitation pour laquelle on peut s'attendre a voir apparaitre le processus de vaporisation. Ce coeftieient est de la forme:

$$
\sigma=\frac{p_{0}-p_{0}}{\xi a_{0}=/ 2}
$$

oì $p_{0}$ et $u_{0}$ sont les valeurs de la pression ef de la vitesse dans le fluide ambiant, $p_{v}$ et $\%$ la tension de vapeur et la masse spécifique du liquide. Un grand nombre de résultats expérimentaux ont montré que la théoric était en bon accord avec la réalité tant qu'il s'agissait d'écoulement sans discontinuité. Mais dès qu'une discontinuilé apparaît, il s'avère que la cavitation prend naissance pour des valeurs de o beaucoup plus srandes que celles que l'on déduit de la distribution des pressions le long de la paroi [1] *, par suite des pressions beaucoup plus basses qui se produisent à l'intérieur des tourbillons prenant naissance dans les zones de discontinuite de vitesse. Pour l'instant, on ne dispose d'aucun moven analytique pour caleuler la raleur de ees pressions.

L'écoulement, à la sortie d'un orifice noyé ou d'une buse, constitue un cas extrème de séparation, car les diverses réactions suivant la naissance et la diffusion d'un tourbillon se répercutent non seulement sur les fluctuations locales, mais aussi sur le mouvement moyen. En d'autres termes, la forme de la paroi n'a absolument aucun effet sur la distribution de pression, et la pression ambiante $p_{0}$ représente également, avec une très bonne approximation, la pression moyenne en tous les points. Si l'on veut prévoir les conditions dans lesquelles un jet noyé commencera à caviter, il faut nécessairement dégager une relation queleonque entre le champ de pression du mouvement turbulent et la vitesse moyenne dans le jet lui-même. Depuis 1949 , l'Institut de Recherches Hydrauliques de Iowa se livre à des recherehes sur l'ensemble et les détails de ce problème: Ia présente communication se propose de faire le point de l'avancement actucl de ces travaux. 


\section{VELOCITY AND PRESSURE FLUCTUATIONS IN THE MIXING ZONE FLUCTUATIONS DE VITESSE ET DE PRESSION DANS LA ZONE DE MELANGE}

From numerous analytical and experimental studies of the mean flow in a submerged jet, the velocity distribution is known to have the characteristics indicated schematically in fig. 1 [2]. Because the modification of the velocity profile is caused entirely by the turbulent mixing, comparison of the successive profiles will show that
D'apres de nombreuses études théoriques et expérimentales portant sur l'écoulement moyen dans un jet noyé, on sait que la distribution des rilesses se présente suivant le sehéma de la figure 1 [2]. Ftant donné que l'évolution des profils de vitesse est entièrement due au mélange turbulent, la comparaison de ces profils successifs montre que la zone de mélange gagne à la fois vers l'intérieur et vers l'extérieur du jel, jusqu'à ce que le noyau original à vitesse constante ait completement disparu. Apres quoi la vilesse dans la zone centrate diminue régulierement au fur et à mesure que se poursuit la diffusion vers l'exléricur. La succession des profils de vitesse (relevés avec un tube a prise dynamique dans un jet d'air de $150 \mathrm{~mm}$ ) est donnée avec plus de détail à la figure 2 .

Sehéma de deference concernant
les caracteristiques
de lécoulement moyen
dans un jot noyé
(Mixing ane = Zone de melange.)

Fia. 2. -... Slagnation-labe measurements of mean longitudinal component of velocity.

Valeurs de la moyenne de la composante longitudinale. de vitesse

d'après les mesures an lube a prise dynamique.

Firi. 3. - Hot-wire measurements of rool-meansquare longitudinal belocily factuation.

Mesures au fil chaude la racine
de la moyenne carre de la
fluctuation Jongitudinate de vitesse.

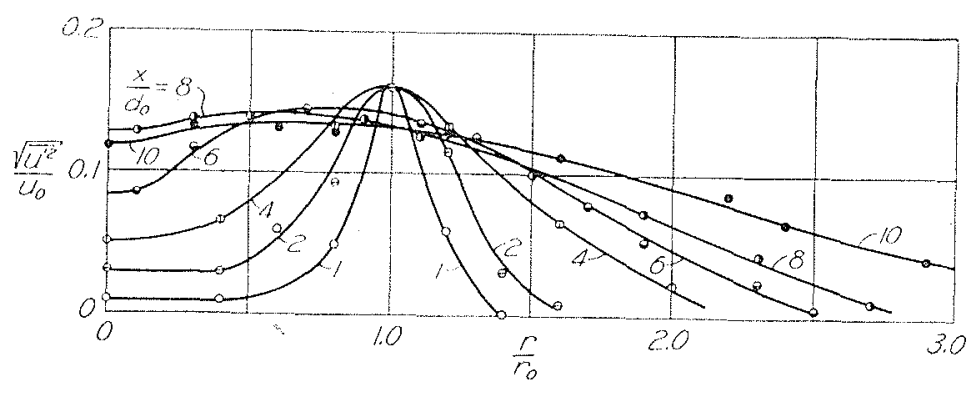

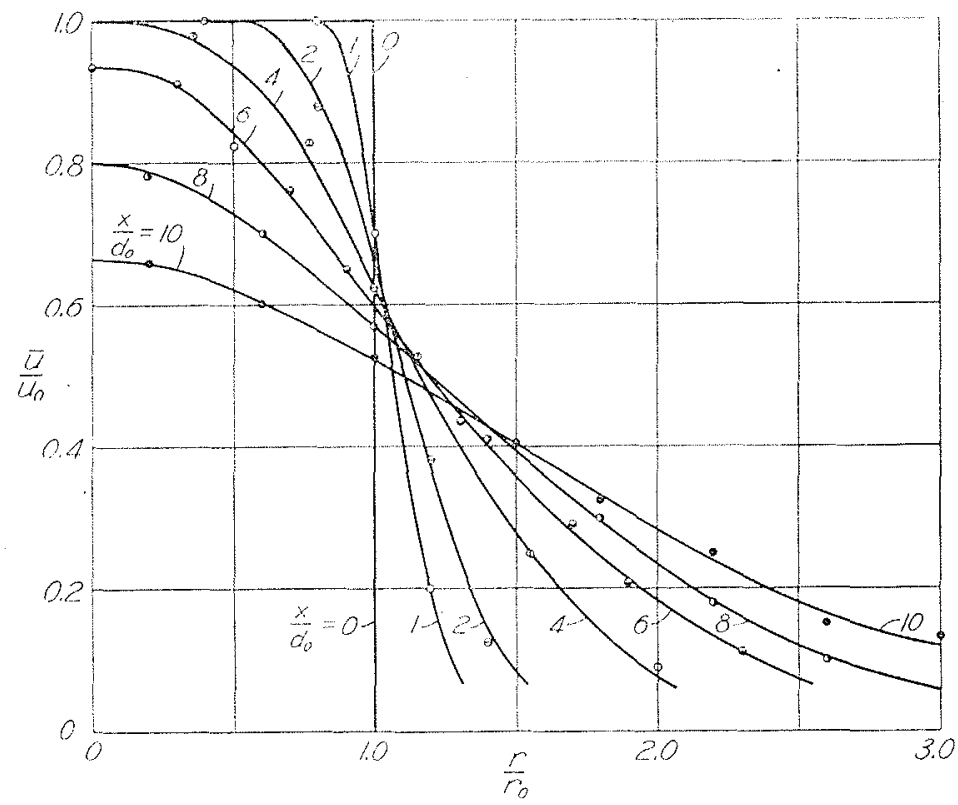

Grâce à des éludes, à la fois thériques et expérimentales, concernant les fluctualions turbulentes, on put recucillir au moins quelques indices relatifs an champ des vitesses dans la zone turbulente de mélange. Les valeurs caracteristiques de la racine de la movenne carrée de la composante longitudinale sont indiquées sur la figure 3 (les mesures étaient faites avec un anémometre à fíl chaud dans un jet d'air de $150 \mathrm{~mm}$ ). Les valeur's des deux autres composantes se répartissent suivant des profils tres voisins, mais leur am- 
the mixing zone spreads inward as well as oulward until the original constant-velocity core entirely disappears, whereafter the velocity of the central zone steadily diminishes as the outward spread continues. The sequence of relocily profiles (measured with a stagnation lube in a 6 -inch jet of air) is presented in more complete detail in fig. 2 .

Both analytical and experimental studies of the secondary action have yielded at least partial information as to the velocity characteristics of the turbulence in the mixing zone. Typical rootmean-square values of the longitudinal component (measured in the 6 -inch jet with a hotwire anemometer) are indicated in fig. 3. Values of the other two components follow essentially similar profiles but have approximately twothirds the magnitude. The maximum intensity of the turbulence is seen from the figure to coincide in radial location with the initial zone of discontinuity, to remain almost constant in magnitude over the length of the constant-velocity core, and then to diminish gradually as the mean velocity itself is reduced.

Since the velocity fluctuations at a given point of observation can be considered to result from the transit of successive eddies, and since the variation in velocity across any eddy entails a particular variation in the intensity of pressure. for every sequence of velocity fluctuations there must exist a specific - albeit unknown sequence of pressure fluctuations. For the case of isotropic turbulence the correlation between the two has been expressed analytically, and Batchelor has found that the ratio of the rootmean-square pressure fluctuation to one-half the product of the density and the mean-square velocity fluctuation - i.e., $1 \overline{p^{2}} /\left(c u^{\prime 2}-2\right)$ - should have the value 1.17 [3].

Unfortunately, the point of incipient jet cavitalion cannot at once be predicted from a value such as this for three pertinent reasons: First of all, the turbulence in a mixing zone is far from isotropic. Secondly, it is not the rootmean-square pressure fluctuation which is significant in cavitation so much as the average negative peak. Thirdly, the theory has been neither checked nor extended experimentally, because instrumentation for the measurement of pressure fluctuations within a mixing zone is still practically nonexistent. Further advancement in the analysis of this phase of turbulence must depend to a considerable degree upon axperimental evidence, and the matter of instrumentation has hence played an important part in the Institute program.

Preliminary results of this nature, which had just become available at the time of writing, plitude est réduite d'environ un liers. D'apres les figures, l'intensité maximum de la turbulence s'avère coïncider dans une section donnée avec Ia zone initiale de discontinuite; son amplitude demeure à peu près constante le long du noyau conique à vitesse constante, puis elle diminue petit a petit en même temps que la vitesse moyenne elle-même diminue.

Puisque les fluctuations de vitesse en un point d'observation déterminé peuvent être considérées comme résultant du passage d'une sucession de tourbillons, et puisque la variation de vitesse au sein de chaque tourbillon entraine une variation locale de la valeur de la pression, on en déduit que, pour chaque série de fluctuations de vitesse, il doit exister une série de fluctuations de pression bien définic mais inconnuc. Dans le cas d'une turbulence isotrope, la corrélation entre ces deux phénomènes a pu êtro expriméc analytiquement, et Batchelor a trouvé que la racine de la moyenne carrée de la fluctuation de pression et le demi-produit de la masse spécifique palr la moyenne carre des fluctuations de vitesse - c'est-à-dire $\sqrt{p^{\prime \prime \prime}} /\left(0 \overline{l^{\prime \prime}} / 2\right) \quad$ cetaient dans le rapport $1,17[3]$.

Malheureusement, et pour lrois bonnes raisons, une relation de ce genre ne permet pas de déterminer directement le point d'apparition de la caviation ans le jet :

Ia premicre de ces rasons, el la plus importante, reside en ee que la turbulence dams une zone de mélange est loin d'etre isolpope. En seeond lieu, ee n'est pas la racine de la moyenne carre des flucluations de pression qui est delerminante pour la cavitation, mais bien la moyeme des minima de pression. Enfin, troisiome rai son, la thérie n’a été ni vérifice ni ćlargie expérimentalement, l'appareillage de mesure des flucluations de pression à l'intérieur d'une zone do mélange etant encore pratiquement inexislant. Les progrès dans l'étude théorique de ce type de turbulence sont, pour une large part, condiliomés par l'obtention de résultats experimenlaux; c'est la raison pour laquelle les problemes d'appareillage tiennent dans les programmes de l'Institut d'Towa une place importante.

Les premiers résultats dans ce domaine - ils viennent juste d'être dégagés au moment où nous ecrivons - ont été obtenus sur le jet d'air dr $150 \mathrm{~mm}$ a l'aide d'un tube de $6 \mathrm{~mm}$ renfermant une prise de pression électromécanique, à l'extrémité de laquelle peuvent être montées deux lètes hémisphériques. L'une de ces lètes comporte un petit orifice à la pointe, l'autre est munie de 4 orifices répartis, de $90^{\circ}$ en $90^{\circ}$ sur le cercle défini par le demi-angle au centre de $47^{\circ} 5$. D'après les essais faits sur un appareil combinć à beaucoup plus grande échelle, on admetlait rue lorifice de la pointe permettait la lec- 
were obtained in the 6 -inch air jet with a $1 / 4$ inch lube enclosing an electro-mechanieal pressure cell, at the end of which two hemispherical heads could be mounted interchangeably. 'The one was provided with a small lip opening, and the other with four openings al $90^{\circ}$ intervals around a circle $47 \%$ from the tip. On the basis of lests made on a composite field instrument at much larger scale, the tip opening was assumed to yield the instantaneous readins $1 / 2 \rho\left(\bar{u}+u^{\prime}\right)^{2}+p^{\prime}-p_{0}$ and the side openings the instantaneous reading $p^{\prime}-p_{0}$. By suitable electronic circuits connected to the pressure cell, the two primary curves plotted dimensionlessly in fig. 4 were determined: the root-mean-squaro longitudinal velocity fluctuation, and the root-
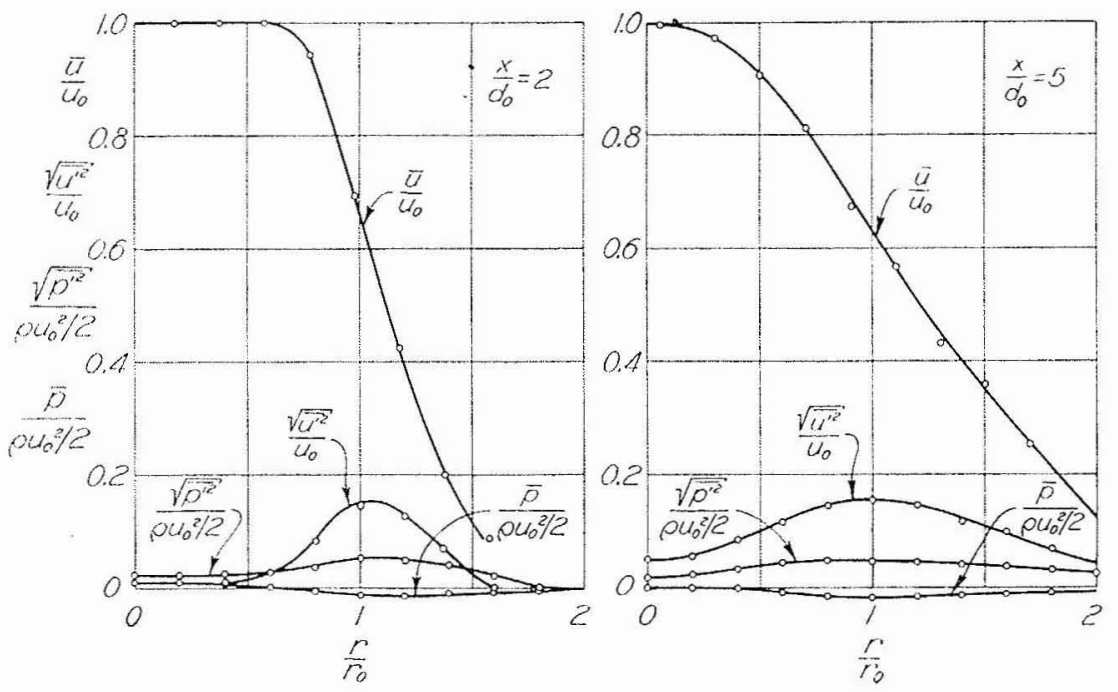

lure instantance de $1 / 2 ?\left(\bar{u}+u^{\prime}\right)=+p^{\prime}-p_{0}$ et les orifices latéraux la lecture instantanée de $\left(p^{\prime}-p_{0}\right)$. Grâce à des circuits électroniques convenables branchés sur la prise de pression, on a pu tracer les deux premières courbes qui sont représentées sur la figure 4 (sans dimensions) : ces deux courbes domnent respectivement la flucluation longitudinale de la racine de la moyenne carrée des vitesses et la fluctuation de la racine de la moyenne carrée des pressions. Les résultats concernant la fluctuation de vitesse s'avèrent coïncider d'assez près avec ceux obtenus avec l'anémomètre à fil chaud; les résultats concernant la fluctuation de pression montrent une tendance analogue. Des renseignements complémentaires relatifs à la précision de l'appareillage sont fournis par les deux autres courbes de la figure dont les éléments ont été obtenus grâce aux deux mêmes têtes combinées avec un manomitre à liquide. La courbe de ritesse moyenne est pratiquement identique à celle qui avait íté obtenue précédemment à l'aide d'une aiguille hypodermique très fine; par contre, la pression moyenne décclée s'écarte légèrement de la valeur zéro prévue, l'écart se révélant lié

Fig. 4. - Velocity and pressure measuremenls obtained with tube and hemispherical heads.

Mesures de vitesse et de pression obtenues arec le tube à tête hémisphérique. mean-square pressure fluctuation. The velocityfluctuation data are seen to agree closely with those obtained by the hot-wire anemometer, and the pressure-fluctuation data follow a similar trend. Further indications as to the accuracy of the instrument are given by the other two curves, the data for which were obtained with the same two tips in conjunction with a liquid manometer. The curve of mean velocity is practically identical to that previously obtained with a very slender hypodermic needle; however, the indicated mean pressure intensity departs from the expected value of zero by a small amount which appears to depend upon the intensity of the velocity fluctuations.

Although these preliminary measurements are merely qualitative, they permit at least a rough evaluation of the pressure fluctuations accomp:nying jet diffusion. The maximum root-meansquare pressure deviation-like the maximmm root-mean-square velocity deviation was found
¿ l'amplitude des fluctuations de pression.

Bien que ces mesures preiminaires soient seulement qualitatives, elles permettent au moins une évaluation approximative des fluctuations de pression qui accompagnent la diffusion du jet. La déviation maximum de la racine de la moyenne carrée des pressions -... de même que la déviation maximum de la racine de la moyenne carrée des vitesses - présente la propriété de demeurer à peu près constante dans la zone initiale de transition : ceci résulte d'un certain nombre d'essais de sondage réalisćs par la suite. Sur la base des valeurs maxima de $\sqrt{!^{\prime 2}} / u_{0}$ et de $\sqrt{\overline{p^{\prime 2}}} /\left(0 u_{0}{ }^{2} / 2\right)$ déduites de la figure 4 , on troure que la quantité $\sqrt{p^{\prime 2}} /\left(0,11^{\prime 2} / 2\right)$ valul environ 2,15 , valeur à rapprocher de la yaleur 1,17 ealculée par Batchelor dans le cas de la turbulence isotrope. La valeur initiale $\sqrt{p^{\prime 2}} /\left(\rho u_{0}{ }^{2} / 2\right)=0,055$ est done significative pour la prévision de la cavitalion sculement si elle est multiplice par un coef- 
from further exploratory tests to remain essentially constant through the initial zone of establishment. If the peak values of $\sqrt{u^{12}} / u_{0}$ and $\sqrt{\overline{p^{\prime 2}}} /\left(\rho u_{0}{ }^{2} / 2\right)$ are taken from fig. 4 as represenlative, it will be found that the quantity $\sqrt{p^{\prime 2}} /\left(\overline{p^{\prime 2}} / 2\right)$ then has a magnitude of about 2.15 , in comparison with that of 1.17 predicted by Batchelor for isotropic turbulence. The primary value $\sqrt{\bar{p}^{\prime 2}} /\left(0 u_{0}{ }^{2} / 9\right)=0.055$ is significant for the prediction of cavitation, however, only if multiplied by a numerical factor embodying the frequency of oceurence.

In arriving at a magnitude for this frequency factor, not only the temporal [4] but also the spatial distribution of the turbulence must be considered. The temporal distribution at any point may be assumed to agree with the normalprobability function, so that definition of incipience as that condition at which cavitation oceurs during a specifed percentage of time will permit a particular multiplying factor to be evaluated. For example, if it is arbitrarily assumed that cavitation has begun when negative fuctuations reach the vapor magnitude $5 \%$ of the time, this factor will have the magnitude $\mathrm{C}_{l}=1.6$. On the other hand, not only a single point but the mixing zone as a whole is involved. Thus, since combination of the temporal frequency with the mean velocity would yield a spatial distribution along only an elementary segment of the mixing zone, this must be mulliplied by an additional spatial factor $\mathrm{C}_{\mathrm{s}}$ representing the number of such segments included in the jet. Although this number is eridently controlled by either the relative scate of the eddy structure or that of the cavities themselves, there is at present no means of determining its masnitude exeept by observation of the eavitation phenomenon itself. For the present, therefore, the index for incipient artation must he written simply as

$$
\sigma_{i}=C_{i} C_{i} \frac{{ }^{\prime} l^{\prime 2}}{o l_{i_{i}}^{2} / 2} .
$$

ficient numérique tenant comple de la fréquence de son apparition.

Pour parvenir à une valeur numérique de ce coefficient de fréquence, il convient de prendre en considération la distribution de la turbulence non seulement dans le temps, mais dans l'espace. Pour ce qui est de la distribution dans le temps en un point queleonque, on peut supposer qu'elle respecte la loi normale de probabilite; des lor's, si l'on définit l'apparition de la cavitation comme le moment à partir duquel la cavitation se produit pendant une fraction déteminéc du temps, on peut calculer un coefficient de correction correspondant. Par exemple, si l'on convient arbitrairement que la cavitution prend naissance lorscue les fluctuations négatives atteignent la tension de vapeur $5 \%$ du temps, ce coefficient aura pour valeur $C_{i}=1,6$. Par ailleurs, ce n'est pas seulement un point isole, mais l'ensemble de la zone de mélange qui intervient. Ainsi, étant donné que la superposition de la fréquence dans le temps et de la vitesse moyenne se traduit par une certaine distribution dans l'espace limité à un segment élémentaire de la zone de mélange, il convient d'adopter un autre coefficient de correction, dit coeffeient spatial $C_{s}$, representant le nombre de tels segments compris dans lo jet. Bien que ee coefficient dépende cridemment soit de l'echolle relative des tombillons, soit de celle des cavités elles-mèmes, il n'existe pour l'inslant aucum moven de calculer sa valeur si co n'est nar l'observation du phónomene de cavitation lui-mème. Pour l'instant, par conséquent, lo critire d'apparition de la eavitation doit etre simolement écrit :

$$
\sigma_{i}=C_{\infty} C_{4} \frac{\sqrt{p^{-3}}}{n_{11}^{2} / 2}
$$

\section{DIRECT OBSERVATIONS OF JET CAVITATION}

\section{OBSERVATIONS DIRECTES DE LA CAVITATION DANS UN JET}

For want of quantitative relationships between the fluctuations of velocity and pressure intensity in a mixing zone, preliminary observations were made in 1949 on the cavitation of a jet produced by a supplementary pumping system in the test section of the smaller Institute water tunnel [5]. Although pronounced cavitation
Afin de rechercher des relations quantitatives entre les fluctuations de vitesse et la pression dans une zone de mélange, quelques observations préliminaires avaient été réalisées en 1949 sur la cavitation d'un jet obtenu srâce ì une station de pompage additionnelle dans le troncon d'essais du plus petit des tumnels hydrodynamiques de 
could readily be obtained, the limited length of the test section was believed to influence the pattern of diffusion to such an extent that measurements were at best merely qualitative. Moreover, unaccountable eflects of temperature upon the incipient cavitation index were noted, even though every effort was made to hold the air content of the water to a minimum. For these reasons a special jel-cavitation tank was constructed the following year.

This lank was 5 leet in diameter and had an orerall length of 10 feet, with convex ends. Nozzles could be mounted interchangeably on a 3 -inch inlet pipe located on the axis at one end, and a 6 -inch oullet pipe was connected at the conter of the other end. A Chryster-Hale fireboat pump was used to provide the required discharge at the necessarily high base pressure. Means of eontrolling the hydrostatic load on the tank, removing air, and either heating or cooling the water were similar to those on the Institute water tunnels [1]. Overall pressures and rates of flow were measured with a large Bourdon gage and a mercury manometer connected to suitable piezometer openings in the walls of the tank and the inlet pipe. The intensity of cavitation was observed through use of a crystal-type Massa hydrophone mounted below the jel on the floor of the lank, the hydrophone being connected through an amplifying circuit to a pen recorder. Background noise was largely eliminated by using a narrow frequency band centered at 25 kilocycles.

From previous caritation investigations it was known that the apparent point of incipience is conleolled to a variable degree by the amount of air carried in suspension as minute bubbles on particles of foreign matter. Although the presence of such nuclei in linited numbers is considered necessary 10 the onset of cavilation, when present to an excessive degree they tend to form cavities within the fluid before the pressure intensity falls to its true vapor magnitude. This corresponds, in effect, to replacing the term $p$, in the cavitation index with a quantity $p$, which depends to an unknown extent upon the amount and nature of the air carried in suspension. Evidently, if both $p_{0}$ and $p_{0}$ are low, this term can play a predominant role in controlling the apparent magnitude of $\sigma$. On the other hand, if both ambient values are high, the magnitude of $p_{c}-$ as well as that of $p_{n}$-.... becomes relatively unimportant. For this reason, every series of cavitation measurements was preceded by 2 or 3 hours of de-aeration at a low late of flow and a very low (i.e., a large negative) hrdrostatic pressure, the air collecting at the top of the lank being removed continuously. The hydrostatic load was then increased by nearly
l'Institut d'lowa [5]. Quoiqu'une cavitation bien établic ait pu être facilement obtenue, on fut amené à penser que la longuear limitée du troncon d'essais influencait l'organisation de la diffusion à un degré tel que les mesures itaient tout au plus qualitatives. De plus, on put remarquer certains effets inexplicables de la température sur lapparition de la cavitation, et ceci même lorsqu'on mettait tout en ouve pour réduire à son minimum la teneur en air de l'eau. Telles sont les raisons qui justifierent la construction, l'année suivante, d'une chambre spéciale pour l'étude de la cavitation des jets.

Cette chambre, convexe à ses deux extrémités, avait un diamètre de $1,50 \mathrm{~m}$ et une longueur hors tout de $3 \mathrm{~m}$. Diverses buses pouvaient être indiféremment nontées sur la conduite d'alimentation de $75 \mathrm{~mm}$ de diametre situéc dans l'axe de la chambre, à l'ume de ses extrémités; au centre de l'autre extrémité dait branchée une conduite de vidange de $150 \mathrm{~mm}$ de diamètre. Une pompe de bateau à incendic (CHRYSLERHALE) permettait d'assurer" le débit demandé sous toute la pression de base nécessaire. Le contrôle de la charge hydrostatique sur la chambre, l'élimination de l'air, le chaufrage ou le refroidissement de l'eau étaient assurés par un appareillage semblable à ceux qui équipent les tunnels hydrodynamiques de l'Institut [1]. Les pressions d'ensemble et les débits ćtaient mesurés avec un gros manometre Bourdon et un manometre a mercure, branchés sur des orifices de prises de pression convenablement disposés dans les parois de la chambre et de la conduite d'amenéc. L'intensité de la cavitation était déceJé par un hydraphone a eristal Massa, disposé sous le jet, sur la paroi inférienre de la chambre cet hrdraphone ctait relic à un enregistreur a plumes par lintermédiaire d'un amplificateur. Le bruit de fond élait en srande partie élimine srace a ladoption d'une bande de fréquence etroite centrée sur 25 kilocycles.

Daprès des recherches anterieures sur la cavitation, on savait que le poinl d'apparition de ce phénomène était, dans une certaine mesure, discernable d'aprés la quanlité d'air transportée en suspension sous forme de tres petites bulles fixées sur des particules solides. Bien que la présence de telles particules, an nonbre limité, soit considérée comme nécessaire pour le déclenchement de la cavitation, elles ont tendance, lorsqu'elles devienment excessivement nombreuses, à former des cavités à l'intéricur du fluide avant que la pression se soit abaisséc réellement jusqu'à la tension de vapeur. En fait, ceci revient à remplacer le terme $\eta_{i}$. dr critive de cavitation

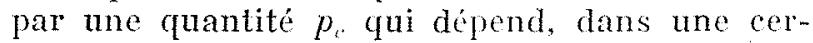
taine mesure que l'on ne connail pas, de la quantité et de la nature de l'air charric en suspension. 
two atmospheres, so that as much as possible of the remaining air would be dissolved. The hydrostatic pressure during the subsequent measurements was held at least 0.5 foot of mercury above that of the de-aeration rum.

Observations with the hydrophone recorder indicated in general that the noise level remained constant with decreasing values of $\sigma$ until the point of incipience was reached, whereupon the noise rapidly increased toward a maximum

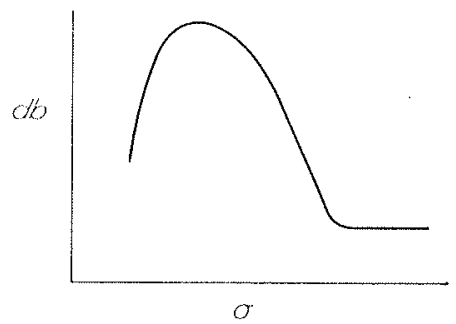

[Fic. 5. Schemalic indication of change in noise leve! with intensity of cavilation.

Forme schematique des variations du niveau sonore en fonction de lintensité de la cavitation.

(fig. 5) and then gradually diminished. Use of a loud-speaker instead of the pen recorder showed the noise just below the point of incipience to be a very sharp crackling; however, at adranced stages it became progressively more mushy, indicating either that the collapse of the cavities wats cushioned by air or that interference of the dispersed cavities affected the noise transmission.

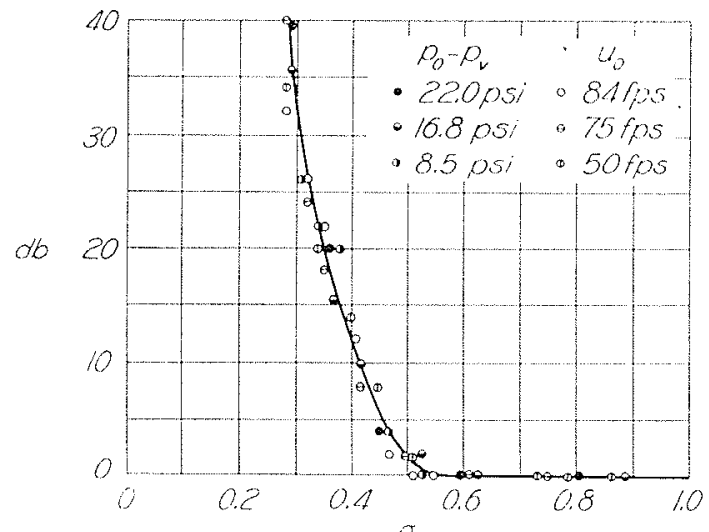

Fiti. (6. - Experimental data for determination of incipient canitation index.

Résullats expérimentaux concermant la determination de lindice de cavitation naissante.

Observations were hence restricted to the zone of incipience, for which mean levels of the cavilation noise were determined at various jel velo. cities, hydrostatic pressures, and water temperatures.

A typical plot of the observed mean noise levels against $\sigma$ is shown in fig. 6 for the jet from a 1:-inch nozzle with a short cylindrical tip.
Evidemment, si $p_{0}$ et $v_{0}$ sont l'un et l'autre pelits, ce terme $p_{0}$ peut jouer un ròle prédominant dans le contrôle de la grandeur apparente de $\sigma$. Par contre, si les deux grandeurs d'ambiance sont élevées, la valeur de $p_{c}$ - de même que celle de $p_{n}$ - - prend une importance relativement faible. Pour cette raison, chaque série de mesures de cavitation était précédée par deux ou trois heures de désaération à faible débit sous très faible pression hydrostatique (c'est-à-dire à valeur négative élevée), l'air recueilli au sommet de la chambre étant continuellement évacué. La charge était alors augmentée d'environ deux atmosphères afin d'assurer la dissolution de la plus grande partie de l'air restant. La pression, durant les mesures ultérieures, était maintenue au moins $15 \mathrm{~cm}$ de mercure au-dessus de celle adoptée dans la phase de désaération.

Les observations faites à l'hydraphone enregistreur montrèrent, en général, que le niveau sonore demeurait constant pour des valeurs décroissantes de $\sigma$, jusqu'à ce que lo point d'apparition de la cavitation soit atteint; le bruit s'amplifiait alors rapidement, atteignait un maximum (fig. 5) puis décroissait graduellement. Si l'on remplace l'enregistreur à plumes par un haut-parleur, on constate, juste en dessous du point d'apparition de la cavitation, un crépitement très aigu; cependant, au fur et à mesure que l'on se rapproche de ce point, ce bruit devient progressivement plus gras, ceci signifiant soit que la résorption des cavités est amortie par l'air, soit que la transmission du bruit est affeclíc par des interférences lices à la dispersion de ces cavités. Les observations furent par suite limitées à la zone d'apparition de la cavitation, dans laquelle les niveaux sonores étaient mesurés pour diverses valeurs de la vitesse du jet, de la pression hydrostatique of de la température de l'oau.

La figure 6 represente un graphique caracteristique des niveaux sonores moyens observés en fonction de $\sigma$, dans le eas d'un jet issu d'une buse de $38 \mathrm{~mm}$ munic d'une petite tête cylindrique. En dépit d'une certaine dispersion, on ne relève aucun écart systématique lié à la pression ou à la vitesse (l'une de ees grandeurs était maintenue constante); de même, (quelques essais complémentaires, menés en faisant varier la température, ne révélèrent aucune influence thermiçue autre que celle s'exercant sur la tension de vapeur. La courbe tracce selon les points relevés donne 0,55 comme grandeur de si, ce crui correspond, pour le produit de $\mathrm{C}_{4}$ et de $\mathrm{C}_{k}$, a 10 environ. Il convient d'insister sur le fait que la courbe relevée correspond seulement à des niveaux sonores moyens, et que l'on observe des intensités sonores instantanées corres- 
Despite a certain amounl of scaller, no systematic deviation with either pressure or velocity (the other being held constant) was noted, nor did supplementary runs in which the temperature was varied show thermal influences beyond that upon the vapor pressure. The line drawn through the plotted points indicales a value of 0.55 for the magnitude of $a_{i}$, corresponding to a product of $\mathrm{C}_{4}$ and $\mathrm{C}_{s}$ of about 10 . The fact should be emphasized that the plotted curve represents mean levels only, and that intermillent flashes of noise were observed at values of - as high as 0.7. Regarded in this light, designation of the point of incipience is just as arbitrary as the selection of a limiting frequency of pressure fluctuation.

Since it is the initial discontinuity between the jet and the surrounding liquid which leads to the generation of the low-pressure eddies, it is to be expected that any rariation in approach conditions which would decrease the rolocity gradient around the jet periphery would also decrease the intensity of the eddy formation and hence lower the magnitude of $\sigma_{i}$. This was demonstrated experimentally by extending the parallel portion of the nozrle tip about 8 diamelers, the resulting boundary-laycr growth reducing the magnitude of $\sigma_{i}$ by $15 \%$. Howerer, complete elimination of the parallel tip (the nozzle then producing a $60^{\circ}$ converging jet) .... also reduced the value of $\sigma_{;}$, but for reasons which are not yet clear. The presence of air in suspension, on the other hand, gave rise to the pseudo-cavitation already discussed, the apparent magnitude of $\sigma_{i}$ then varying with the magnitude of $p_{0}$ and with the air concentration over a wide range. Under these circumstances, a design value of 0.6 for $\sigma_{i}$ seems a reasonable average.

Efforts to photograph the cavitation pockets in the diffusion zone further emphasized many of the points which have heen discussed. In order to eliminate blurring of the image, highspeed $(1 / 20,000$ second $)$ illumination was used. Just below the point of incipience, the chance of catching a readily visible vapor pocket with a single exposule was found to be negligible. At a sufficiently low value of $\sigma$, of course, representative cavities were always recorded, as shown in the upper photograph of fig. 7 obtained with rear illumination. In order to reveal the radial distribution of the cavities, a condensing lens and slot were used to produce a thin (1/4inch) sheet of light at right angles to the camera axis. Then, however, multiple exposures were necessary to ensure the presence of cavities in sufficient densily. The second photograph, obtained in this manner, shows clearly the outline of the cavitation zone. Noteworthy is the fact that - although the zone of maximim cavitation pondant à des o valant jusqu'à 0,7 . Vue sous cet angle, la détermination du point d'apparition de la cavitation est tout aussi arbitraire que lo choix d'une fréquence limite de la fluctuation de pression.

Etant donné que c'est la discontinuite inilialo entre le jet et le fluide environnant qui provoque l'apparition des tourbillons a basse pression, il faut s'attendre à ce que toute modification des conditions aux limites tendant à réduire le gradient de vitesse à la périphérie du jet ralentisse la formation des tourbillons et finalement abaisse la valeur de $\sigma_{i}$. Ceci fut confrmé expérimentalement en allongeant jusqu'à 8 diametres la portion cylindrique de la tête de buse: il en résulte un épaississement de la couche limite provoquant lui-même une réduction de $\sigma_{i}$ de $15 \%$. Cependant, l'élimination totale de la tête cylindrique (la buse produit alors un jet convergent at $60^{\circ}$ ) provoque également une réduction de $\sigma_{j}$, mais pour des raisons rui sont encore obscures. Par ailleurs, la présence d'air en suspension donnait naissance à la pseudo-cavitation dont nous avons déjà parlé; la valeur apparente de $\sigma_{i}$ variait alors dans de larges proportions suivant la grandeur de $p_{0}$ et la concentration en air. Dans de telles conditions, il semble raisonnable d'assigner comme valeur moyenne à $\sigma_{i}: 0,6$.

Les tentatives faites en vue de photographier les poches de cavitation dans la zone de diffusion permirent de mettre en lumiere beaucoup des points discutés. Afin d'éviter un brouillage de l'image, on opère avec des éclairs extrêmement brefs $\left(1 / 20.000^{\circ}\right.$ de sec). En se placant leserement en dessous du point dapparition de la cavitation, on avait constaté que la chance (le saisir, avec une seule prise de vue, une pocho de vapeur aisément visible, était négligeable. Pour une valeur suffisamment faible de $\sigma$, on relevail évidemment toujours des cavités caractéristiques, ainsi que le montre la photographie superieure de la figure 7 obtenue avec un éclairage à l'arriereplan. Afin de faire apparaitre la distribution radiale des cavités, un jeu de fentes et de lentilles permettait de réaliser une nappe lumineuse mince $(6 \mathrm{~mm})$, normale a l'axe de l'appareil photographique. Mais alors, il fallait de nombreuses expositions pour s'assurer la présence d'une densité suffisante de poches de cavitation. La seconde photographie de la figure 7 , obtenue suivant cette méthode, montre clairement le contour de la zone de cavitation. Un fait est remarcuable : bien que la zone de cavitation maximum coüncide généralement avec la zone de turbulence maximum, on ne décèle pas de formation de vapeur tout le long d'un tróncon initial d'environ 1 diamètre. Les caractéristiques de la zone de résorption - en dehors du champ de ces photographies - demandent encore des recherches. 
coincides in general with the zone of maximum turbulence - no vapor formation is evident over an initial length of about one diameter. The characteristics of the zone of collapse - beyond the range of these photographs - L have yet to bo investigated.
En résumé, il convient de noter que les éléments rassemblés jusqu'à maintenant sont surtout des sondages indiquant, plutôl que des résultats définitifs utilisables de suite en pratique, les directions dans lesquelles doivent être menées des observations plus détaillées.
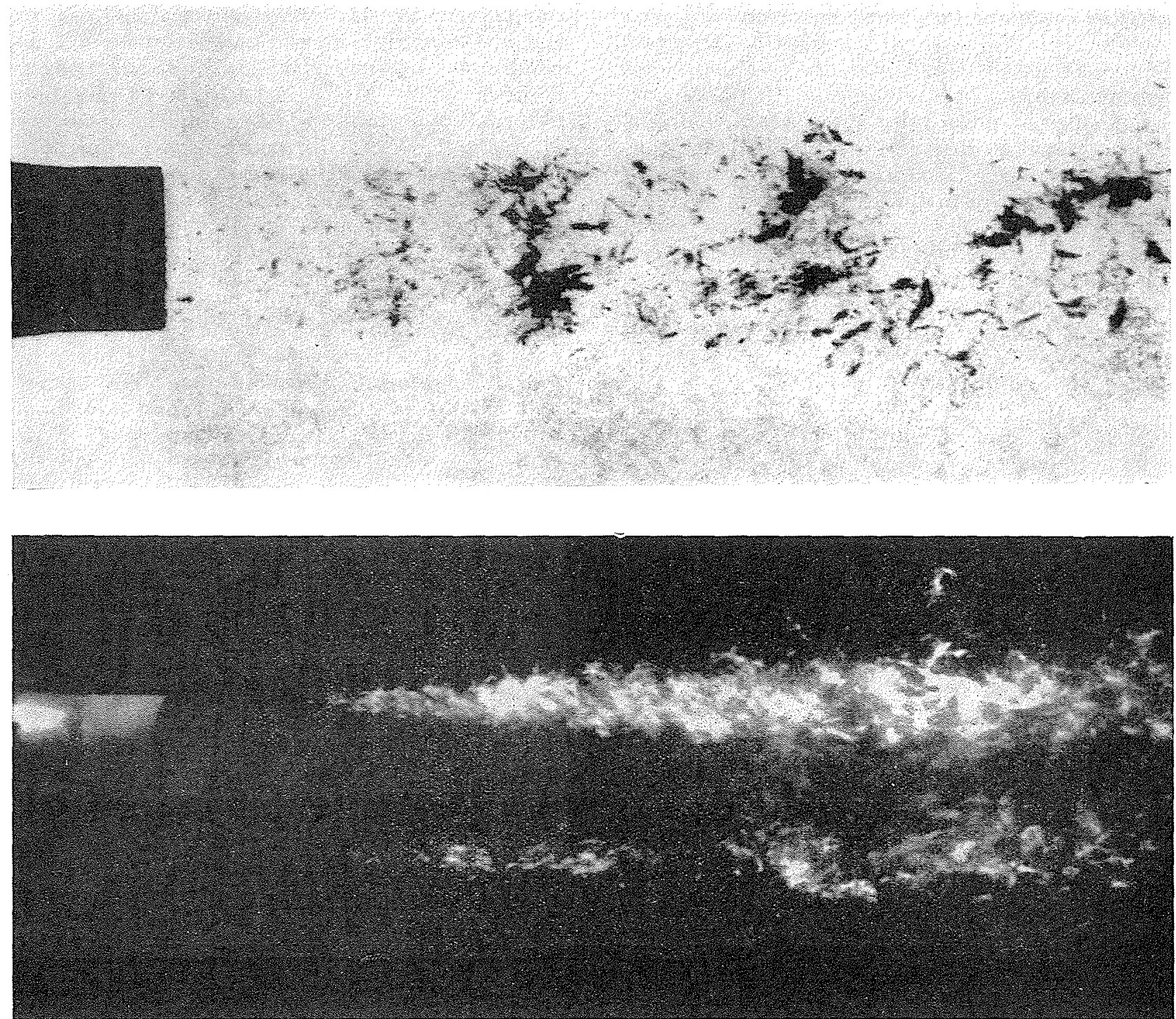

FiG. 7. - Photographs of jet cavilation at $\sigma=0.2$. Abone. single exposure with rear illumination. Below, 25 exposures with only central plane illuminated.

Photographies de la cavitation dans le jet pour $\sigma=0$,2. En haut, une seule exposition avec éclairage ì l'arrière-plan. En bas, 25 expositions mais en éclairant seulement un plan central.

By way of summary, it must be noted that accomplishments to date have been largely of an exploratory nature, indicating directions for more refined observations rather than final values for immediate use. The pressure tube shows promise of permitting a cquantitative study
Le tube de prise de pression semble permettre d'envisager l'étude quantitative des fluctuations instantanées, à condition' que la tête puisse être réalisée suffisamment petite par rapport à la zone de diffusion et suffisamment exempte d'erreur systématique; comme le tube dynamique, il pré- 
of the instantaneous fluctuations, provided that the tip can be made sufficiently small relative to the diffusion zone and free from appreciable bias; like the velocity tube, it has the particular advantage of being adaptable to use in both air and water. The matter of the spatial distribulion of eavities will probably require an investigation of scale as well as intensily, by melhods which are still far from obvious. And for an analysis of the complete history of a typical cavity, it will be necessary to carry both pressure measurements and photographic observalions from the nozzle itself to the point of collapse. The only numerical result now at hand is that determined empirieally for the point of incipient cavitation of an initially parallel jet with even velocity distribution and minimum air content; under these conditions, the design value $\sigma_{i}=0.6$ is considered to represent a dependable figure.

All experiments described herein were conducted at the Iowa Insitute of Hydranlic Research under Contract N8onr-500 with the Office of Naval Research. Measurements of the veiocity characteristics were made by H. C. Hsu and those of the pressure characteristics by S. C. ling, mith instruments developed maler the direction of P. G. Hubbard. Investigations of tho cabitation ilself were conducled as a graduale thesis project by J.P. Whitehonse [6]. The paper was presented by the anthor at the Eighth International Congress on Theoretical and Applied Vechanics, Istanbul, 195?. sente l'avantage considérable de pouvoir ètre utilisé aussi bien dans l'eau que dans l'air. En ce qui concerne la distribution spatiale des poches de vapeur, il faudra probablement se livrer a des rechorches d'échelle et d'intensité, par des méthodes qui sont encore loin d'être au point. Pour ce qui est de l'analyse de l'evolution complete d'une poche caractéristique, il faudra nécessairement mener de front des mosures de pression et des observations photographiques depuis l'extrémité de la buse elle-mème jusqu'au point de résorption. Le seul résultat numélique dont on dispose actuellement est celui qui a cté déterminé empiriquement pour le critère d'appa rition de la cavitation dans un jet primitivement parallele, avec distribution regulicre de vitesse, et concentration en air minimum; dans de telles conditions, on peut, avec une certaine confiance, assigner à $\sigma_{i}$ la valeur de 0,6 .

Tous les essais decrits ci-dessus ont été réalisés it l'Institut de Recherches Hydranliques d'lowa, par contrat N 8 onr-500 passé avec l'Office de Recherches Navales. Les mesures des caracteristiques de vitesses sont dues a $\mathrm{H}$. C. Hse et colles des caracteristiques de pressions it S. C. Lrva; l'appareillage a éte mis au point sous la direction de P. G. Hrabund. hes rechorehes sur la caviation olle-meme étaient effeclues par J. P. Whatranoss: [0] dans le cadre d'un projel de these. Cotte note a fait l'objet d'ane Communicalion an $8^{\circ}$ Conques International de Mécanique Theorigue et Applinuée. en 195\%, at Istanbul.
1 Rouse, H., and MoSoms. J. S., \% Cavialion alld Pressure Distribulion - Head Forms at Zeon Angle al Jaw $\geqslant$, Bulletin 32, Studies in finginecentus, Stale Enirersity of Iowa, 1948.

12 Armarson, M. L., DAr, Y. B., Jexiser, R. A., and Rouse, MUNere, « Diffusion of Submerged Jots, Trans. A.S.C.E., Vol, 115,1950, p. B39, 1945.

(3) Batcheror, G. K., " Pressme Fluctuations in Isotropic Turbulence, » Proc. Camb. Phil. Soc. 47, part 2, p. 369, April 1951.

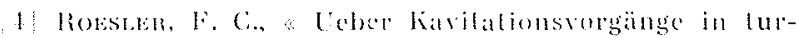

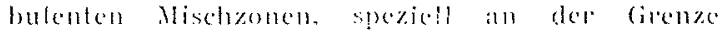

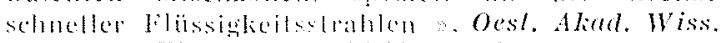
malh-nat. Kl. Anz. $87,28 \vec{i}-290,1950$.

6) Rouse, H., Hebmand P. C., and Sprexgo, A. C., * Caritation of Submerged Jets, » Ioval Institute of Hydratic Rescarch, Interin Report to office of Naval Research, Mareh 1950.

6] Whrerouse, J. P., \& An Investigation into the Point of Incipient Cavitation of Submerged Jets, $\Rightarrow$ M. S. thesis, State University of Towa, February 1952. 